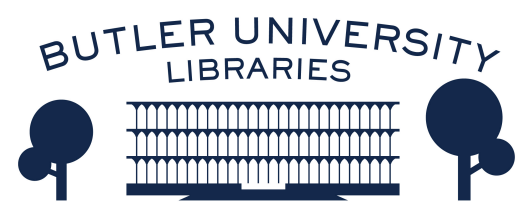

Journal of Hindu-Christian Studies

Volume 21

Article 18

January 2008

\title{
Book Review: "Bishop Stephen Neill: From Edinburgh to South India"
}

Adam Dodds

Follow this and additional works at: https://digitalcommons.butler.edu/jhcs

Part of the Religion Commons

\section{Recommended Citation}

Dodds, Adam (2008) "Book Review: "Bishop Stephen Neill: From Edinburgh to South India"," Journal of Hindu-Christian Studies: Vol. 21, Article 18.

Available at: https://doi.org/10.7825/2164-6279.1417

The Journal of Hindu-Christian Studies is a publication of the Society for Hindu-Christian Studies. The digital version is made available by Digital Commons @ Butler University. For questions about the Journal or the Society, please contact cbauman@butler.edu. For more information about Digital Commons @ Butler University, please contact digitalscholarship@butler.edu. 


\section{Bishop Stephen Neill: From Edinburgh to South India. Dyron B. Daughrity. New York: Peter Lang, 2008, x + 305pp.}

IN this clearly written and thoroughly researched volume the author offers a historical biography of Bishop Stephen Charles Neill from 1900-1945. One of the greatest twentieth century Christian statesmen, Neill remains something of a mystery. Daughrity's aim is to shed light on this mystery in seven main chapters each with a useful introduction and conclusion.

This introductory chapter offers a brief overview of Neill's life and describes the three contributions Daughrity seeks to make by publishing this volume. First, this volume is the first published monograph on Neill. Daughrity claims that given Neill's stature as a twentieth century missiologist this work is "long overdue" (12). Second, many of the primary sources surrounding Neill's India years have been untouched until now. His conflict with Amy Carmicheal (chapter four) and the reasons for his dismissal as bishop (chapter seven) are particularly noteworthy. Third, this biography of Neill serves as a prism of history, illuminating early $20^{\text {th }}$ century Christianity in England, latecolonial India, missions history and Indian nationalism. As historical biography the author proposes his work to rank alongside other recent historical biographies of Christian statesman, specifically Keith Clements' Faith on the Frontier: A Life of $J$. H. Oldham (Edinburgh: T \& T Clark, 1999) and Susan B. Harper's In the Shadow of the Mahatma: Bishop V. S. Azariah and the Travails of Christianity in British India (Grand Rapids: Eerdmans, 1999). The central thesis of Daughrity's book is that the first half of Neill's life is best interpreted through an examination of his internal and external conflicts.

A description of Neill's peripatetic missionary parents, their evangelical Christian piety, their love for India, and also Neill's father's severe health problems form the beginning of chapter two (1900-1924). Inheriting each of these family characteristics, Neill's internal conflict consisted chiefly in his health struggles. Daughrity chronicles Neill's unbounded academic successes first at Dean
Close School and then at Cambridge University where he read classics and theology.

Chapter three changes focus as the author describes the conflicted history of the Tinnevelly mission and diocese in south India of which Neill would later become bishop. The causes of conflict include the cultural clash of Western versus Indian religion and education, missionary society rivalry, mass conversion causing social disturbance, and nascent nationalistic rumblings.

Neill's mysterious first step on his Indian missionary journey is the content of chapter four (1924-1928). Daughrity notes that Neill's autobiography, God's Apprentice, omits any mention of both Amy Carmichael and Dohnavur. Although previous scholars have suggested that Neill did serve in Carmichael's Dohnavur mission, Daughrity claims to be the first to historically establish this fact. He also sheds much-needed light on why an accomplished historian like Neill would fail to mention his first period of missionary service. By the author's reckoning, Amy Carmichael was "an individual every bit as strong-minded and obstinate as Neill." (93) Neill and Carmichael repeatedly locked horns until Neill finally left, leaving both parties deeply wounded.

Chapter five describes Neill the educator as Principal first of Union Christian College (192829) and later Nazareth Seminary (1930-39). The author shows how Neill was frustrated with this role, preferring pioneer evangelism to theological education. Neill also contributed to the formation of the Church of South India over which he had conflicted feelings.

By contrast, chapter six describes Neill's years as bishop of Tinnevelly (1939-1945) which the author describes as "the least conflicted of his life to this point because he was in control, he made the decisions, and there was no authority with whom he could conflict, for he was bishop." (155) Daughrity describes Neill's rise to the bishopric, his ministry in Tinnevelly, and his autocratic and imperialistic tendencies. He also highlights Neill's evangelistic zeal, his love for his diocese and his untiring work on its 
behalf.

Chapter seven is the climax of this book. It focuses entirely on 1944-1945 and the reasons for Neill's departure from India. Daughrity describes the "conspiracy of silence" that surrounded Neill's departure from India and Bishop Richard Holloway's breaking of that silence. Daughrity's contribution is a careful historical reconstruction of what happened. Among Neill's many external and internal conflicts, Indian nationalism and his sadomasochistic tendencies chiefly contributed to his departure from India.

The final chapter offers a brief conclusion. Daughrity shows that despite Neill's undoubted guilt regarding the accusations that led to his downfall, his widespread popularity was such that his tenure as bishop is seen as the golden age in Tinnevelly's history.

With three useful appendices of primary sources on Neill, a list of archives consulted and interviews undertaken, further bibliographic information and an index, Daughrity rounds off his volume.

The author's 'conflict thesis' seems overstretched initially, but the evidence accumulates as the book develops, climaxing in chapter seven by which time the thesis becomes quite compelling. He traces the origins and development of this internal conflict within Neill and shows how this conflict marks his career and friendships, with serious consequences.
Although the author believed the examination of the possible causes of Neill's sadism to be outside of his remit, some obvious connections with Neill's school experiences could have been highlighted. Despite the necessary historical exposition of Neill's downfall, one sympathises with those conspirators of silence who were concerned to emphasise Neill's great achievements for which he is remembered. These achievements do feature, but by using the conflict thesis as an interpretive tool they are occasionally recast in a more negative light. One feels that Neill's deep spirituality and faithfulness to Christ, as well as his honesty and sustained courage, are rather under-represented and overshadowed.

The sporadic repetition of quotations and the occasional typographical errors aside, Daughrity has produced a commendable historical biography. Of the three contributions he claims to make to scholarship he succeeds particularly well in his first two, whilst the third is underdeveloped. Neill's life, "at once so promising, yet so hamstrung by conflict" (5) was indeed the enigma Daughrity described. One hopes that Daughrity, or another so capable, undertakes a complementary volume on the second half of the life of Bishop Stephen Neill.

Adam Dodds

University of Otago, New Zealand

\section{The Crisis of Secularism in India. Edited by Anuradha Dingwaney Needham and Rajeswari Sunder Rajan. Durham: Duke University Press, 2007, xii + 411.}

THE essays in this volume address the "crisis of secularism" in India, a crisis which, the editors suggest, emerged during the Emergency and culminated in the 2002 Gujarat violence (1). While this particular "crisis" may be an Indian one, the editors argue that it is but one manifestation of a tension which lies at the very heart of democratic secularism, a tension between the need for national unity and the desire to preserve and allow for religious difference. By virtue of their electoral politics, secular democracies place the majority in a position of dominance over minorities such that in the quest for national unity religious minorities are left with an undesirable choice: relinquish their distinctive identities or risk being seen as traitors, spoilers, or foreigners.

The volume will be of interest to readers of $J H C S$ because of the way these issues affect Christianity and Hindu-Christian relations in India. While some of the essays address the interaction of Hindus and Christians directly, in other cases, the relevance to such topics is of the tangential variety. For example, the first section 